\title{
Pengungkapan Corporate Sosial Responsibility, Media Exposure dan Profitabilitas
}

\author{
Erwin Saraswati ${ }^{1}$ \\ Fakultas Ekonomi dan Bisnis \\ Universitas Brawijaya, Indonesia
}

\author{
Upik Nindi Febryanti2 \\ Fakultas Ekonomi dan Bisnis \\ Universitas Brawijaya, Indonesia
}

\section{Ananda Sagitaputri ${ }^{3}$ \\ Fakultas Ekonomi dan Bisnis Universitas Brawijaya, Indonesia}

\begin{abstract}
Surel : erwin@ub.ac.id
ABSTRAK

Penelitian ini bertujuan untuk menguji pengaruh pengungkapan Corporate Social Responsibility (CSR) pada profitabilitas perusahaan, dengan media exposure sebagai variabel pemoderasi. Sampel yang diteliti adalah 15 perusahaan agrikultur yang terdaftar di Bursa Efek Indonesia periode 2016-2018. Data diolah menggunakan Moderated Regression Analysis (MRA). Hasil penelitian menunjukkan bahwa pengungkapan CSR tidak dapat meningkatkan profitabilitas perusahaan, sedangkan media exposure terbukti memiliki pengaruh langsung pada profitabilitas perusahaan. Berdasarkan teori legitimasi, CSR merupakan usaha perusahaan untuk menyesuaikan dengan nilai dan norma masyarakat. Oleh karena itu, agar mendapatkan legitimasi atau pengakuan dari masyarakat, CSR harus diungkapkan melalui media yang dapat dengan mudah diakses masyarakat, sehingga manfaat dari CSR dapat direalisasi menjadi keuntungan. Dengan demikian, perusahaan diharapkan dapat lebih banyak menggunakan website atau media sosial untuk mengomunikasikan kegiatan CSR-nya.
\end{abstract}

Kata Kunci: Corporate Sosial Responsibility; Pengungkapan Profitabilitas; Media Exposure.

\section{Disclosure of Corporate Social Responsibility, Media Exposure and Profitability}

\begin{abstract}
This research examined the impact of corporate social responsibility (CSR) disclosure on firms' profitability moderated by media exposure. The samples selected were 15 agricultural firms listed on Indonesian Stock Exchange for the period of 2016-2018. The data were analyzed using Moderated Regression Analysis (MRA). The result showed that CSR disclosure do not affect ROA, but media exposure had a direct effect to ROA. Based on the legitimacy theory, firms conduct CSR to align with societal values and norms. To earn legitimacy from the society, CSR needs to be communicated to channels that are easily accessed by the people, so the benefits of CSR can be realized into profits. Based on the research results, companies are expected to use their websites or social media more often to communicate their CSR activities.
\end{abstract}

Keywords: Corporate Sosial Responsibility; Disclosure; Profitability; Media Exposure.

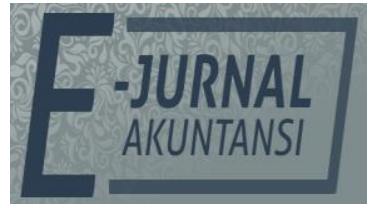

e-ISSN 2302-8556

Vol. 30 No. 12

Denpasar, Desember 2020

Hal. 3209-3219

DOI:

10.24843/EJA.2020.v30.i12.p17

PENGUTIPAN:

Saraswati, E., Febryanti, U.N., \& Sagitaputri, A. (2020). Pengungkapan Corporate Sosial Responsibility, Media Exposure dan Profitabilitas. E-Jurnal Akuntansi, 30(12), 3209-3219

RIWAYAT ARTIKEL: Artikel Masuk: 8 Oktober 2020 Artikel Diterima: 14 Desember 2020

Artikel dapat diakses : https://ojs.unud.ac.id/index.php/Akuntansi/index 


\section{PENDAHULUAN}

Corporate Social Responsibility (CSR) menjadi bagian penting dalam agenda perusahaan saat ini. Pada dasarnya CSR merupakan gagasan yang dapat berdampak positif bagi perusahaan dan masyarakat. Akan tetapi, hal ini terhalang oleh sifat alamiah perusahaan yang berorientasi pada maksimalisasi keuntungan (Yaparto et al., 2013). CSR dapat menciptakan keunggulan kompetitif bagi perusahaan (Maqbool \& Zameer, 2018), namun juga memerlukan waktu dan biaya (García-Sánchez et al., 2019). Oleh karena itu, banyak peneliti tertarik untuk menguji pengaruh CSR terhadap bottom line atau profitabilitas perusahaan. Meskipun telah banyak diteliti, namun hasilnya masih beragam. Sejumlah besar studi menemukan bahwa CSR dapat meningkatkan kinerja keuangan perusahaan (Suciwati et al., 2016), (Kholis, 2014), (Bidhari et al., 2013), (Chandrayanthi \& Saputra, 2013) dan (Luthan et al., 2012). Namun, Sari et al., (2016) menemukan bahwa pengungkapan CSR menurunkan profitabilitas. Hal serupa ditemukan oleh Septiana \& DP (2012) bahwa biaya kesejahteraan berpengaruh negatif terhadap return on assets (ROA). Beberapa penelitian menemukan pengaruh tidak signifikan (Yaparto et al., 2013), (Wijayanti \& Prabowo, 2011), (Fauzi et al., 2007), dan (Sarumpaet, 2005).

Terdapat tiga pandangan berbeda mengenai pengaruh CSR terhadap profitabilitas perusahaan (Maqbool \& Zameer, 2018). Pandangan pertama yang bersifat positif umumnya mengacu pada teori stakeholder. Hammann et al. (2009) menemukan bahwa melalui CSR, perusahaan mampu menciptakan nilai untuk para pemangku kepentingan, kemudian berpengaruh positif terhadap kinerja keuangan. Berdasarkan prespektif pelanggan, CSR dapat menjaga hubungan baik dengan pelanggan, meningkatkan loyalitas pelanggan, serta mempertahankan dan memperluas pasar (Maqbool \& Zameer, 2018), (Saleh, 2008), dan (Porter \& Kramer, 2011). Apabila dari segi pekerja, CSR dapat menciptakan kondisi kerja yang baik, sehingga meningkatkan moral dan produktivitas karyawan, serta menarik tenaga kerja yang berkualitas (Maqbool \& Zameer, 2018), dan (Luthan et al., 2012). CSR ditemukan dapat memperbaiki citra perusahaan, kemudian dapat mengurangi risiko kebangkrutan (Hammond \& Slocum, 1996). Dengan demikian, berinvestasi pada CSR, perusahaan dapat meningkatkan profitabilitasnya (Maqbool \& Zameer, 2018).

Pandangan negatif mengenai CSR menyatakan bahwa hubungan antara perusahaan dengan stakeholder tidak bersifat resiprokal (Anggraini, 2006). Pandangan ini berpendapat bahwa manfaat dari CSR tidak sebanding dengan biaya yang dikeluarkan. CSR menimbulkan biaya yang besar bagi perusahaan, seperti donasi, peralatan produksi dan pengembangan produk ramah lingkungan, pengolahan limbah dan polusi, serta kesehatan dan keselamatan kerja (Maqbool \& Zameer, 2018), dan (Lindrawati et al., 2008). Bagi pemegang saham, biaya untuk CSR dapat dianggap sebagai sebuah kerugian, karena mengakibatkan berkurangnya dividen (Lindrawati et al., 2008).

Pandangan netral menyatakan bahwa CSR dan kinerja keuangan perusahaan merupakan dua hal yang tidak saling terkait. Apabila ditemukan korelasi antara keduanya, kemungkinan besar temuan tersebut hanyalah sebuah kebetulan, karena terlalu banyak faktor yang bekerja diantaranya (Maqbool \& Zameer, 2018). Hal ini disebabkan banyaknya faktor yang bekerja untuk 
fluktuasi kinerja keuangan atau profitabilitas perusahaan. Adapun seringkali stakeholder tidak mempertimbangkan faktor CSR dalam pengambilan keputusan, karena stakeholder menganggap pengungkapan CSR perusahaan tidak sesuai standar dan bias pada pengungkapan informasi positif saja (Yaparto et al., 2013).

Pada dasarnya, CSR ditujukan untuk membentuk citra perusahaan yang sustainable dan telah memenuhi ekspektasi dari masyarakat. Untuk mencapai tujuan tersebut, perusahaan perlu melakukan pengungkapan tanggung jawab sosialnya (O'Donovan, 2002). Perhatian masyarakat terhadap pengungkapan sosial dan lingkungan perusahaan semakin meningkat akibat maraknya penggunaan media (Arshad \& Vakhidulla, 2011). Salah satu media yang paling efektif untuk penyampaian informasi CSR adalah website perusahaan (Sari et al., 2019). Website perusahaan pun dapat diakses secara mudah dan luas, sehingga penyamapaian informasi CSR melalui website perusahaan diharapkan dapat memengaruhi pengambilan keputusan publik. Studi sebelumnya menemukan bahwa media exposure merupakan salah satu faktor terpenting yang mempengaruhi tingkat pengungkapan CSR (Arshad \& Vakhidulla, 2011), dan (Reverte, 2009).

Mayoritas penelitian pada bidang pengungkapan tanggung jawab sosial perusahaan dikaitkan dengan teori legitimasi dan teori stakeholder. Legitimasi dapat diartikan sebagai kondisi di mana aktivitas perusahaan telah selaras dengan nilai dan norma yang berlaku di masyarakat. Untuk mendapatkan legitimasi, yaitu meyakinkan masyarakat bahwa perusahaan telah menyelaraskan aktivitas bisnisnya dengan nilai dan norma yang berlaku di masyarakat, perusahaan perlu melakukan pengungkapan sosial dan lingkungan kepada publik (O'Donovan, 2002). Pengungkapan sosial dan lingkungan juga merupakan bentuk pertanggungjawaban perusahaan atas dampak yang perusahaan timbulkan pada kondisi sosial dan lingkungan sekitarnya, serta untuk menghindari potensi konflik sosial dan lingkungan (Ghozali \& Chariri, 2007).

Teori stakeholder menyebutkan bahwa suatu perusahaan dan para pemangku kepentingannya saling mempengaruhi satu sama lain (Hadi, 2010). Perusahaan memerlukan stakeholder yang suportif, dan masyarakat memerlukan perusahaan untuk menciptakan lapangan pekerjaan (Porter \& Kramer, 2011). Hal ini menyebabkan eksistensi perusahaan dipengaruhi oleh para pemangku kepentingan, dan perusahaan perlu memberikan manfaat bagi para pemangku kepentingannya (Devina et al., 2004) dan (Ghozali \& Chariri, 2007). Untuk mempertahankan hubungan dengan para pemangku kepentingan, manajemen melakukan pengungkapan informasi berdasarkan kebutuhan para pemangku kepentingan (Gray et al., 2001).

Pengaruh pengungkapan CSR terhadap kinerja keuangan perusahaan telah diteliti oleh beberapa peneliti sebelumnya. Namun, penelitian-penelitian tersebut belum menghasilkan temuan yang konklusif. Sejumlah penelitian berikut menemukan bahwa pengungkapan CSR berpengaruh positif terhadap kinerja keuangan. Suciwati et al. (2016) meneliti 15 perusahaan sektor pertambangan di Bursa Efek Indonesia (BEI) periode 2010-2013, dan menemukan bahwa pengungkapan CSR meningkatkan return on assets (ROA) dan return on equity (ROE). Kholis (2014) meneliti 34 perusahaan manufaktur yang terdaftar di BEI 
periode 2007-2008 dan menemukan hasil serupa bahwa pengungkapan CSR meningkatkan kinerja keuangan yang diproksikan dengan ROA, ROE, dan return on sales (ROS). Luthan et al. (2012) meneliti 45 perusahaan manufaktur yang terdaftar di BEI periode 2011-2014, dan menemukan bahwa pengungkapan CSR meningkatkan ROA, namun tidak berpengaruh terhadap Tobin's Q.

Sejumlah penelitian lain menghasilkan temuan yang berbeda. Yaparto et al. (2013) meneliti 79 perusahaan manufaktur yang terdaftar di BEI periode 20102011, dan menemukan bahwa pengungkapan CSR tidak berpengaruh signifikan terhadap ROA, ROE, maupun EPS. Sari et al. (2016) meneliti 9 perusahaan multinasional yang terdaftar di BEI dan 10 perusahaan multinasional yang terdaftar di Bursa Efek Malaysia periode 2012-2015. Hasil penelitian ini menunjukkan bahwa pengungkapan CSR di Indonesia lebih tinggi dibandingkan Malaysia, namun pengungkapan di Indonesia justru menurunkan performa keuangan dan nilai perusahaan. Perusahaan multinasional Malaysia, pengungkapan CSR meningkatkan kinerja keuangan dan nilai perusahaan. Hal ini disebabkan kegiatan CSR di Indonesia menimbulkan biaya yang signifikan, sedangkan manfaatnya tidak sebanding akibat kurangnya kesadaran dari masyarakat mengenai isu sosial dan lingkungan.

Terdapat dua celah penelitian dalam literatur yang sudah ada. Pertama, terdapat keberagaman hasil dalam penelitian-penelitian sebelumnya. Kedua, penelitian sebelumnya hanya terbatas pada sektor-sektor tertentu seperti manufaktur (Kholis, 2014), (Yaparto et al., 2013), dan (Luthan et al., 2012), pertambangan (Suciwati et al., 2016), (Chandrayanthi \& Saputra, 2013), atau perbankan (Bidhari et al., 2013). Oleh karena itu, penelitian ini bertujuan mengisi celah penelitian tersebut dengan meneliti pengaruh pengungkapan CSR pada profitabilitas 15 perusahaan sektor agrikultur yang terdaftar di BEI periode 20162018. Penelitian ini akan memperhitungkan media exposure sebagai variabel pemoderasi antara pengaruh pengungkapan CSR terhadap profitabilitas. Sektor agrikultur dipilih karena mendapat sorotan dari masyarakat atas operasinya yang berdampak pada ekosistem dan habitat satwa, serta penggunaan genetically modified organisms (GMO) dan pestisida (Mazur-Wierzbicka, 2015), serta, kaitan CSR terhadap profitabilitas perusahaan agrikultur belum banyak diteliti pada penelitian sebelumnya.

Berdasarkan teori stakeholder, terdapat hubungan resiprokal antara CSR dan para pemangku kepentingan (Luthan et al., 2012), karena pengungkapan CSR dapat memberikan value untuk stakeholder yang kemudian menjadi keunggulan kompetitif bagi perusahaan (Maqbool \& Zameer, 2018). Berdasarkan teori legitimasi, dengan mengatasi masalah yang ada di masyarakat, perusahaan dapat memperoleh kesempatan untuk memperluas pasarnya, meningkatkan reputasi, dan membentuk kesetiaan pelanggan (Maqbool \& Zameer, 2018), (Porter \& Kramer, 2011), dan (Saleh, 2008). Selain itu, CSR dapat meningkatkan kualitas working condition dan sehingga meningkatkan moral dan produktivitas karyawan (Luthan et al., 2012), dan (Maqbool \& Zameer, 2018). Dengan demikian, secara tidak langsung pengungkapan CSR dapat meningkatkan performa finansial perusahaan. Beberapa studi sebelumnya telah menemukan hubungan positif antara pengungkapan CSR dan profitabilitas perusahaan 
(Maqbool \& Zameer, 2018), (Kholis, 2014), (Suciwati et al., 2016), dan (Luthan et al., 2012). Berdasarkan uraian tersebut, maka disusun hipotesis sebagai berikut.

$\mathrm{H}_{1}$ : Pengungkapan CSR berpengaruh positif terhadap profitabilitas.

Untuk meyakinkan masyarakat bahwa perusahaan telah menyelaraskan aktivitas bisnisnya dengan nilai dan batasan dari masyarakat, perusahaan perlu menyebarluaskan informasi tersebut kepada masyarakat (O'Donovan, 2002). Media internet atau web perusahaan merupakan media yang paling efektif dengan semakin banyaknya pengguna internet di Indonesia (Sari et al., 2019). Dengan mengkomunikasikan CSR melalui web perusahaan, semakin banyak masyarakat yang dapat mengetahui aktivitas CSR perusahaan, sehingga profitabilitas diekspektasikan dapat memperkuat pengaruh pengungkapan CSR terhadap kinerja keuangan. Sari et al., (2019) menemukan bahwa media exposure memperkuat hubungan positif antara pengungkapan CSR dan nilai perusahaan. Berdasarkan uraian tersebut, maka disusun hipotesis sebagai berikut.

$\mathrm{H}_{2}$ : Media exposure memperkuat pengaruh pengungkapan CSR terhadap profitabilitas.

\section{METODE PENELITIAN}

Penelitian ini menggunakan pendekatan kuantitatif dengan metode Moderated Regression Analysis (MRA) untuk menguji pengaruh pengungkapan CSR (CSRD) terhadap return on assets (ROA) dengan media exposure sebagai variabel pemoderasi. Data pengungkapan tanggung jawab sosial diambil dari laporan tahunan perusahaan. Data keuangan diperoleh dari laporan keuangan perusahaan yang ada di website Bursa Efek Indonesia, sedangkan data media exposure diperoleh dari website resmi perusahaan sebagaimana tercantum dalam website Bursa Efek Indonesia.

Variabel independen dalam penelitian ini, tanggung jawab sosial perusahaan, diukur menggunakan pendekatan dikotomi, yaitu setiap item CSR dalam instrumen penelitian diberi nilai 1 jika diungkapkan dalam laporan tahunan dan nilai 0 jika tidak. Instrumen yang digunakan dalam penelitian ini mengacu pada penelitian Sembiring (2005). Instrumen ini digunakan karena telah banyak digunakan dalam penelitian CSRD di Indonesia seperti Suciwati (2016), Kholis (2014), dan Yaparto et al., (2013). Instrumen yang digunakan dalam penelitian ini mengandung 78 indikator pengungkapan yang dikelompokkan menjadi 7 kategori, yakni: (1) lingkungan, (2) energi, (3) kesehatan, (4) keselamatan tenaga kerja, (5) produk, (6) keterlibatan masyarakat, dan (7) umum. Setelah melakukan penilaian pada laporan tahunan, skor dari setiap observasi dijumlahkan dan dibagi dengan nilai maksimum yaitu 78 , sehingga perhitungan yang dilakukan sebagai berikut.

CSRD $=$ jumlah item yang diungkapkan $/ 78$.

Variabel dependen dalam penelitian ini adalah profitabilitas yang diukur dengan return on assets (ROA). ROA menggambarkan besarnya laba yang dihasilkan perusahaan apabila dibandingkan dengan total aktiva. ROA digunakan untuk mengukur kemampuan perusahaan menghasilkan laba. Semakin tinggi ROA suatu perusahaan, semakin baik kinerja perusahaan tersebut. ROA memberikan informasi seberapa efisien suatu dalam melakukan usahanya, karena rasio ini mengidentifikasikan berapa besar keuntungan dapat 
diperoleh rata-rata terhadap setiap setiap rupiah asetnya. Rumus perhitungan ROA sebagai berikut.

ROA = Laba setelah pajak / Total aktiva

Variabel pemoderasi dalam penelitian ini adalah media exposure (ME). Penelitian ini mengukur media exposure dengan variabel dummy, yaitu memberikan nilai 1 untuk perusahaan yang memiliki laman khusus kegiatan CSR di website resmi perusahaan dan nol untuk sebaliknya. Model penelitian yang digunakan dalam penelitian ini adalah sebagai beriku.

$\mathrm{ROA}=\alpha+\beta_{1} \mathrm{CSRD}+\beta_{2} \mathrm{ME}+\beta_{3} \mathrm{CSRD} * \mathrm{ME}+\varepsilon$.

\section{HASIL DAN PEMBAHASAN}

Berdasarkan statistik deskriptif pada Tabel 1, variabel pengungkapan CSR (CSRD) jatuh pada rentang 12,8\%-79,5\%, dengan rata-rata 26,0\% dan standar deviasi 19,2\%. Hal ini berarti praktik pengungkapan CSR di Indonesia masih beragam, akibat longgarnya aturan mengenai standar pengungkapan CSR di laporan tahunan. Kemudian profitabilitas perusahaan yang diproksikan oleh return on assets (ROA) jatuh pada rentang 0,03\%-29,70\%, dengan rata-rata 4,25\% dan standar deviasi 5,36\%. Variabel media exposure (ME) yang merupakan variabel dummy memiliki rata-rata $62 \%$, yang memiliki arti bahwa $62 \%$ perusahaan (28 observasi) memiliki laman khusus CSR pada website, sedangkan 17 perusahaan sisanya belum memiliki laman khusus CSR. Tabel 1, menyajikan statistik deskriptif untuk ketiga variabel yang diteliti.

\section{Tabel 1. Statistik Deskriptif}

\begin{tabular}{llcccc}
\hline Keterangan & $\mathrm{N}$ & Minimum & Maksimum & Mean & Std. Dev. \\
\hline CSRD & 45 & 0,128 & 0,795 & 0,269 & 0,192 \\
ROA & 45 & 0,000 & 0,297 & 0,042 & 0,054 \\
ME & 45 & 0,000 & 1,000 & 0,620 & 0,490 \\
\hline
\end{tabular}

Sumber: Data Penelitian, 2020

Untuk memastikan bahwa model yang digunakan telah memenuhi kondisi best linear unbiased estimator (BLUE), dilakukan uji asumsi klasik berupa uji multikolinearitas, uji heteroskedastisitas, dan uji autokorelasi dan normalitas data. Uji multikolinieritas bertujuan untuk menguji apakah dalam model regresi terdapat korelasi antar variabel independen. Berdasarkan hasil pengujian multikolinieritas menggunakan Variance Inflation Factor (VIF) diketahui bahwa nilai VIF tiap variabel independen berada di bawah 10. Dari hasil tersebut dapat disimpulkan bahwa model regresi yang digunakan bebas multikolinieritas.

Uji autokorelasi dilakukan untuk memastikan efisiensi dari estimator. Jika terdapat masalah autokorelasi, interval kenyakinan menjadi lebar dan model tidak dapat digunakan. Hasil pengujian autokorelasi menunjukkan nilai Durbin Watson sebesar 1,021, yang jatuh pada interval aman yaitu antara -2 dan +2 . Hal ini menunjukkan dalam model regresi tidak ada permasalahan autokorelasi.

Uji heteroskedastisitas bertujuan untuk menguji apakah dalam model regresi terjadi ketidaksamaan varians dari residual dari satu pengamatan ke pengamatan yang lain. Berdasarkan hasil pengujian heteroskedastisitas diketahui bahwa titik- titik yang terbentuk pada grafik scaterplot tidak membentuk pola yang jelas serta tersebar di atas dan di bawah angka 0 pada sumbu Y. Sehingga 
dapat diambil kesimpulan bahwa model regresi yang digunakan bebas heteroskedastisitas.

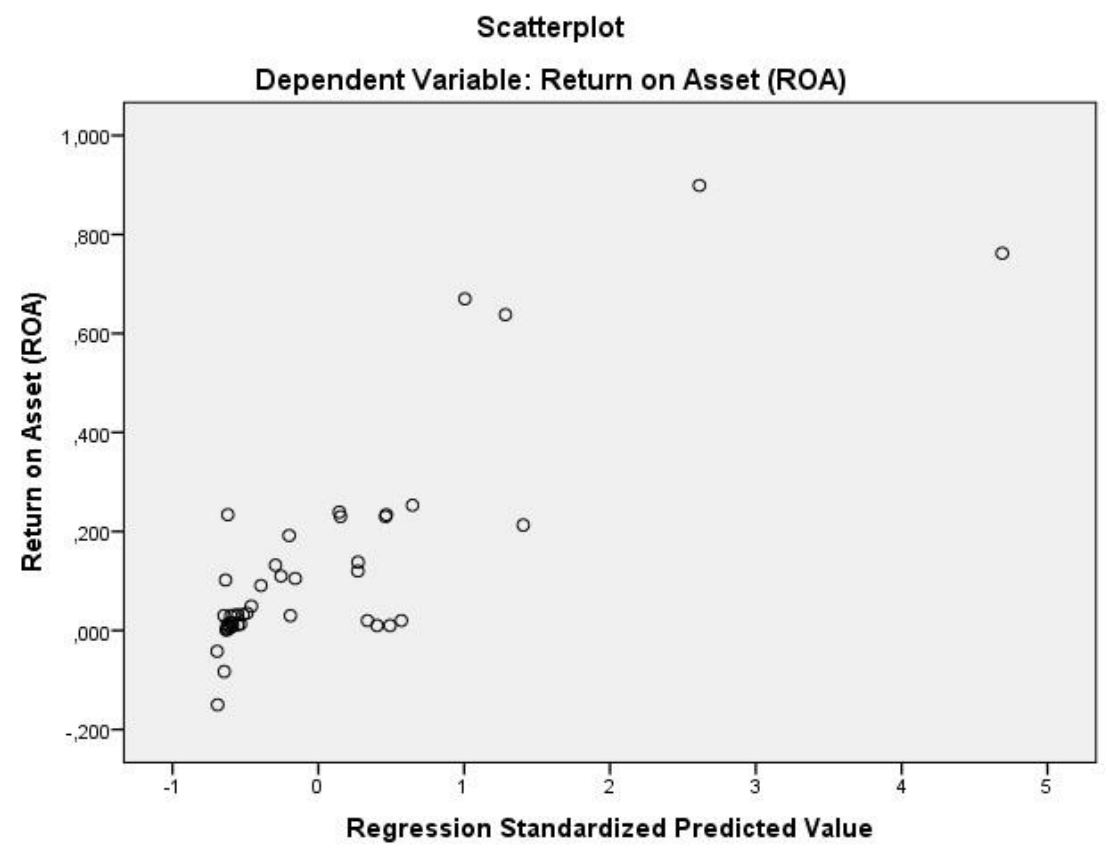

Sumber: Data Penelitian, 2020

Gambar 1. Uji Heteroskedastisitas

Uji normalitas bertujuan untuk menguji apakah variabel penganggu atau residual dalam model regresi memiliki distribusi normal. Berdasarkan hasil uji Kolmogorov-Smirnov (KS) diperoleh nilai signifikansi sebesar 0,230 $(a>0,05)$. Berdasarkan hasil tersebut maka data yang digunakan dalam penelitian ini berdistribusi normal. Pengujian hipotesis dilakukan dengan Moderated Regression Analysis (MRA).

Tabel 2. Hasil Moderated Regression Analysis (MRA)

\begin{tabular}{lccc}
\hline Model & $\mathrm{B}$ & $\mathrm{t}$ & Sig. \\
\hline (Constant) & 0,010 & 0,291 & 0,773 \\
CSRD & 0,011 & 0,084 & 0,933 \\
ME & 0,219 & 2,283 & $* *) 0,028$ \\
Pemoderasi & 0,993 & 4,871 & $* * *) 0,000$
\end{tabular}

Keterangan:

$* * *)$ signifikansi pada $1 \%$

**) Signifikansi pada $5 \%$

Sumber: Data Penelitian, 2020

Berdasarkan hasil regresi pada Tabel 2, uji $t$ atas CSRD menunjukkan signifikansi di atas 0,05. Hal ini berarti hipotesis I tentang CSRD berpengaruh positif terhadap ROA ditolak. Hipotesis II tentang media exposure memperkuat pengaruh positif CSRD terhadap ROA diterima dengan signifikansi 1\%. Hasil regresi menemukan bahwa media exposure memiliki pengaruh positif signifikan langsung kepada ROA. Dengan kata lain, pengungkapan CSR di laporan tahunan tidak memengaruhi profitabilitas, namun CSR yang dipublikasikan di website akan meningkatkan profitabilitas. 
Hasil penelitian ini konsisten dengan penelitian sebelumnya (Yaparto et al., 2013), (Wijayanti \& Prabowo, 2011), (Fauzi et al., 2007), dan (Sarumpaet, 2005) yang menemukan pengaruh pengungkapan CSR tidak dapat meningkatkan profitabilitas perusahaan. Hal ini sesuai dengan pandangan netral mengenai CSR yang menyatakan bahwa bahwa CSR dan kinerja keuangan perusahaan merupakan dua hal yang tidak saling terkait dan terlalu banyak faktor yang bekerja diantaranya (Maqbool \& Zameer, 2018). Yaparto et al., (2013) dan stakeholder perusahaan Indonesia belum mempertimbangkan CSR dalam pengambilan keputusan, karena seringkali pengungkapan CSR di laporan tahunan tidak sesuai dengan core perusahaan, dan cenderung hanya mengungkapkan informasi yang positif saja.

Meskipun luas pengungkapan CSR pada laporan tahunan tidak berpengaruh pada profitabilitas, hasil penelitian menemukan bahwa ketika perusahaan mempublikasikan kegiatan CSR-nya di website perusahaan, profitabilitas perusahaan akan meningkat. Hal ini menunjukkan bahwa pelaporan di website lebih efektif dibandingkan di laporan tahunan. Hal ini memperkuat temuan Sari et al., (2019) bahwa media internet atau web perusahaan merupakan media yang paling efektif dengan semakin banyaknya pengguna internet di Indonesia. Demikian juga dengan penelitian dari Kesavan et al,. (2013) yang menyarankan perusahaan untuk menggunakan media sosial untuk mengkomunikasikan kegiatan CSR-nya. Sosial media juga berfungsi sebagai sarana pemasaran word of mouth untuk meningkatkan pasar perusahaan (Kesavan et al., 2013).

Penelitian ini berhasil mendukung pengungkapan CSR menyebabkan peningkatan kinerja diperkuat oleh media exposure. Salah satu faktor terpenting yang mempengaruhi tingkat pengungkapan CSR adalah media (Arshad \& Vakhidulla, 2011), dan (Reverte, 2009). Hal ini mengindikasikan inevestor akan mempertimbangkan faktor media dan mendukung teori legitimasi, bahwa dengan mengkomunikasikan CSR melalui web perusahaan, semakin banyak masyarakat yang dapat mengetahui aktivitas CSR perusahaan, sehingga profitabilitas diekspektasikan dapat memperkuat pengaruh pengungkapan CSR terhadap kinerja keuangan.

\section{SIMPULAN}

Hasil penelitian ini menunjukkan bahwa pengungkapan CSR tidak dapat meningkatkan kinerja perusahaan. Penelitian ini konsisten dengan beberapa penelitian yang menyatakan pengungkapan CSR di negara berkembang hanya bersifat simbolis, bukan substantive, agar dapat diterima oleh masyarakat. Hasil ini mendukung teori legitimasi. Sebaliknya, penelitian ini berhasil menemukan bahwa pengungkapan CSR dapat meningkatkan kinerja, jika diperkuat oleh media exposure. Media web saat ini merupakan sarana yang efektif untuk menyampaikan kegiatan CSR perusahaan.

Berdasarkan teori legitimasi, CSR merupakan usaha perusahaan untuk menyesuaikan dengan nilai dan norma masyarakat. Oleh karena itu, untuk mendapatkan legitimasi atau pengakuan dari masyarakat, CSR harus diungkapkan melalui media yang dapat dengan mudah diakses masyarakat, sehingga manfaat dari CSR dapat direalisasi menjadi keuntungan. Dengan 
demikian, penyebarluasan informasi CSR lebih efektif melalui website perusahaan dibandingkan pada laporan tahunan perusahaan, sehingga perusahaan diharapkan dapat lebih gencar menggunakan media untuk mengomunikasikan kegiatan CSR-nya.

Keterbatasan dari penelitian ini adalah terdapat subjektivitas peneliti dalam pengukuran pengungkapan CSR, sehingga peneliti selanjutnya menggunakan asisten peneliti agar lebih obyektif. Selain itu, sektor agrikultur hanya sedikit yang mengungkapkan laporan CSR, sehingga sampel relative sedikit. Penelitian selanjutnya, dapat menggunakan data survey, untuk meneliti secara lebih mendalam pada sektor agrikultur.

\section{REFERENSI}

Anggraini, F. R. R. (2006). Pengungkapan informasi sosial dan faktor-faktor yang mempengaruhi pengungkapan informasi sosial dalam laporan keuangan tahunan (Studi empiris pada perusahaan-perusahaan yang terdaftar Bursa Efek Jakarta). Simposium Nasional Akuntansi, 9(23-26).

Arshad, H., \& Vakhidulla, Z. (2011). Determinants of CSR Disclosure in the Swedish Setting - Effect of firm/industry charecteistics along with media exposure on CSR disclosure practices. LUP Student Papers. http://lup.lub.lu.se/student-papers/record/1976744

Bidhari, S. C., Salim, U., Aisjah, S., \& Java, E. (2013). Effect of corporate social responsibility information disclosure on financial performance and firm value in banking industry listed at Indonesia stock exchange. European Journal of Business and Management, 5(18), 39-46.

Candrayanthi, A. A., \& Saputra, I. D. G. D. (2013). Pengaruh pengungkapan corporate social responsibility terhadap kinerja perusahaan (studi empiris pada perusahaan pertambangan di bursa efek Indonesia). E-Jurnal Akuntansi Universitas Udayana, 4(1), 141-158.

Chariri, A., \& Ghozali, I. (2007). Teori Akuntansi. Badan Penerbit Universitas Diponegoro.

Devina, F. (2004). Pengaruh Karakteristik Perusahaan terhadap Pengungkapan Sosial dalam Laporan Tahunan Perusahaan Go Publik di Bursa Efek Jakarta. In Doctoral Dissertation, Program Pascasarjana Universitas Diponegoro.

Fauzi, H., Mahoney, L. S., \& Abdul Rahman, A. (2007). The link between corporate social performance and financial performance: evidence from Indonesian companies. Issues in Social and Environmental Accounting, 1(1), 149-159.

García-Sánchez, I., Hussain, N., Martínez-Ferrero, J., \& Ruiz-Barbadillo, E. (2019). Impact of disclosure and assurance quality of corporate sustainability reports on access to finance. Corporate Social Responsibility and Environmental Management, 26(4), 832-848. https:/ / doi.org/https:/ / doi.org/10.1002/csr.1724

Gray, R., Javad, M., Power, D. M., \& Sinclair, C. D. (2001). Social and environmental disclosure and corporate characteristics: A research note and extension. Journal of Business Finance \& Accounting, 28(3-4), 327-356.

Hadi, N. (2010). Corporate Social Responsibility. Graha Ilmu.

Hammann, E. M., Habisch, A., \& Pechlaner, H. (2009). Values that create value: 
socially responsible business practices in SMEs-empirical evidence from German companies. Business Ethics: A European Review, 18(1), 37-51.

Hammond, S. A., \& Slocum, J. W. (1996). The impact of prior firm financial performance on subsequent corporate reputation. Journal of Business Ethics, 15(2), 159-165.

Kesavan, R., Bernacchi, M. D., \& Mascarenhas, O. A. (2013). Word of mouse: CSR communication and the social media. International Management Review, 9(1), $58-66$.

Kholis, N. (2014). Pengaruh Corporate Social Responsibility terhadap Kinerja Keuangan Perusahaan Sektor Manufaktur. IQTISHADIA, 7(2), 223-248.

Lindrawati, Felicia, N., \& Budianto. (2008). Pengaruh Corporate Social Responsibility terhadap Kinerja Keuangan Perusahaan yang Terdaftar Sebagai 100 Best Corporate Citizens oleh KLD Research \& Analytics. Majalah Ekonomi, 66-83.

Luthan, E., Rizki, S. A., \& Edmawati, S. D. (2018). Pengaruh pengungkapan tanggung jawab sosial perusahaan terhadap kinerja keuangan. EKUITAS (Jurnal Ekonomi Dan Keuangan), 1(2), 204-219.

Maqbool, S., \& Zameer, M. N. (2018). Corporate social responsibility and financial performance: An empirical analysis of Indian banks. Future Business Journal, 4(1), 84-93.

Mazur-Wierzbicka, E. (2015). The application of corporate social responsibility in European agriculture. Miscellanea Geographica, 19(1), 19-23.

O'Donovan, G. (2002). Environmental disclosures in the annual report: Extending the applicability and predictive power of legitimacy theory. Accounting, Auditing $\mathcal{E}$ Accountability Journal, 15(3), 344-371. https:// doi.org/https://doi.org/10.1108/09513570210435870

Porter, M. E., \& Kramer, M. R. (2011). Creating Shared Value. Harvard Business Review, 89(1-2), 62-77.

Reverte, C. (2009). Determinants of corporate social responsibility disclosure ratings by Spanish listed firms. Journal of Business Ethics, 88(2), 351-366.

Saleh, M., Zulkifli, N., \& Muhamad, R. (2008). An empirical examination of the relationship between corporate social responsibility disclosure and financial performance in an emerging market. 16th Annual Conference on Pacific Basin Finance Economics Accounting Management (PBFEAM), 1-22.

Sari, M. N., \& Mukhzarudfa, Y. (2019). Pengaruh Pengungkapan Corporate Social Responsibility dan Profitabilitas Terhadap Nilai Perusahaan Dengan Media Exposure Sebagai Variabel Moderating (Studi Pada Perusahaan Perkebunan yang Terdaftar di Bursa Efek Indonesia, Malaysia dan Singapura). Jurnal Akuntansi \& Keuangan Unja, 4(2), 68-75.

Sari, W. A., Handayani, S. R., \& Nuzula, N. F. (2016). Pengaruh Pengungkapan Corporate Social Responsibility Terhadap Kinerja Keuangan dan Nilai Perusahaan (Studi Komparatif pada Perusahaan Multinasional yang Terdaftar di Bursa Efek Indonesia dan Bursa Malaysia Tahun 2012-2015). Jurnal Administrasi Bisnis, 39(2), 74-83.

Sarumpaet, S. (2005). The relationship between environmental performance and financial performance of Indonesian companies. Jurnal Akuntansi Dan Keuangan, 7(2), 89-98. 
Sembiring, E. R. (2005). Karakteristik Perusahaan dan Pengungkapan Tanggung Jawab Sosial: Studi Empiris pada Perusahaan yang Terdaftar di BEJ. Simposium Nasional Akuntansi VIII.

Septiana, R. A., \& DP, E. N. (2012). Pengaruh Implementasi Corporate Social Responsibility Terhadap Profitabilitas Perusahaan (Studi pada Perusahaan Manufaktur yang Listing di BEI 2007 sd 2009). PEKBIS (Jurnal Pendidikan Ekonomi Dan Bisnis), 4(2), 71-84.

Suciwati, D. P., Pradnyan, D. P. A., \& Ardina, C. (2016). Pengaruh Corporate Social Responsibility Terhadap Kinerja Keuangan. Jurnal Bisnis Dan Kewirausahaan, 12.

Wijayanti, F. T., \& Prabowo, M. A. (2011). Pengaruh Corporate Social Responsibility terhadap kinerja keuangan perusahaan. Simposium Nasional Akuntansi XIV.

Yaparto, M., Frisko, D., \& Eriandani, R. (2013). Pengaruh Corporate Social Responsibility Terhadap Kinerja Keuangan Pada Sektor Manufaktur Yang Terdaftar Di Bursa Efek Indonesia Pada Periode 2010-2011. Calyptra, 2(1), 119. 